Journal of Physical Science, Vol. 32(1), 57-68, 2021

\title{
The Efficiency of Natural Dyes-based Dye Sensitised Solar Cells
}

\author{
Motlan $^{1,2^{*}}$ and Nurdin Siregar ${ }^{1,2}$ \\ ${ }^{1}$ Department of Physics, Universitas Negeri Medan, Medan, Indonesia \\ ${ }^{2} \mathrm{Jl}$. Willem Iskandar Pasar V Medan Estate, 20221 Medan, Indonesia \\ ${ }^{*}$ Corresponding author: motlan@unimed.ac.id
}

Published online: 25 April 2021

To cite this article: Motlan \& Siregar, N. (2021). The efficiency of natural dyes-based dye sensitised solar cells. J. Phys. Sci., 32(1), 57-68. https://doi.org/10.21315/jps2021.32.1.5

To link to this article: https://doi.org/10.21315/jps2021.32.1.5

\begin{abstract}
ZnO/natural dyes solar cell (DSSC) had been successfully synthesised. The preparation of $\mathrm{ZnO}$ thin films was carried out on an indium thin oxide (ITO) glass substrate using the sol-gel spin coating method. The natural dyes were extracted from tamarillo, red dragon fruit, red spinach, boat lily flower and purple hibiscus flower, each cut into small pieces and put into a beaker glass. The sample was then further crushed with a mortar and then milled until it became soft. The extracted dyes were heated for $5 \mathrm{~h}$ and diluted with distilled water to obtain dye solutions. The DSSC structure was formed by glueing together the ZnO/dye and a platinum plat by using Surlyn. The ZnO/dye and platinum were successively used as a working electrode and counter electrode. The Surlyn functioned as glue and conductor. The DSSC structure then put on a hot plate with a temperature of $70^{\circ} \mathrm{C}-80^{\circ} \mathrm{C}$ to enable Surlyn pasted perfectly. Further, electrolyte liquid was injected into the $\mathrm{ZnO}$ /dye-platinum structure. The $\mathrm{ZnO}$ thin films were characterised by X-ray powder diffraction (XRD), scanning electron microscope (SEM) and UV-Vis spectrometer. The $\mathrm{ZnO}$ /natural dyes thin films were formed by dipping the $\mathrm{ZnO}$ thin film into natural dyes solution with the $\mathrm{ZnO}$ thin films facing up for $24 \mathrm{~h}$ to let the dyes adsorbed by the film. DSSC efficiencies were measured by a simple circuit consisting of DSSC, both analogue and digital multimeters. The results showed that the $\mathrm{ZnO}$ crystal structure was of wurtzite hexagonal shape with a crystallite size of $27.3 \mathrm{~nm}$, high-density granules with narrow inter granules boundary, and the band-gap was $3.25 \mathrm{eV}$. The maximum and minimum values of the sensitisers were from red spinach and red dragon fruit which were 3.30 a.u and 2.50 a.u. The DSSC can convert solar energy to electrical energy with power and efficiency of consecutively of $0.101 \mathrm{~W} \mathrm{~cm}^{-2}$ and $0.278 \%$.
\end{abstract}

Keywords: DSSC, crystal structure, $\mathrm{ZnO}$ thin film, natural dyes, purple hibiscus flower

(C) Penerbit Universiti Sains Malaysia, 2021. This work is licensed under the terms of the Creative Commons Attribution (CC BY) (http://creativecommons.org/licenses/by/4.0/). 


\section{INTRODUCTION}

Thin layer solar cell energy conversion recently had gained interest in the development of a thin solar cell due to its cost-effectiveness and relatively simple technology. One of the thin layer cells is the $\mathrm{ZnO}$ /natural dyes solar cell (DSSC) introduced by previous researchers. ${ }^{1,2}$ DSSC comprises several components such as oxide semiconductor, dye, counter electrode and electrolyte. The choice and the way of processing of the semiconductor as well as the dyes are the main area of research to improve the quality of the DSSC which aims to produce highefficiency DSSC-based solar cell. The research involves many physical and technological parameters such as the active layers composition, thickness, optical parameters and density of defects. ${ }^{3}$ Semiconductor engineering, the dye molecular structure, the electrolyte oxidation-reduction pair and electrode materials are among important aspects that first need to be improved.

$\mathrm{ZnO}$ is one of the most attractive candidates for the oxide semiconductor due to its physical properties. $\mathrm{ZnO}$ semiconductor exhibits multifunction properties with high bond energy, low resistivity and high light capture. ${ }^{4}$ Besides, the $\mathrm{ZnO}$ has a wideband gap of $3.37 \mathrm{eV}$, high optical transparency at room temperature and the ability to bind a free electron of $60 \mathrm{meV} .{ }^{5}$ The $\mathrm{ZnO}$-based thin film has been applied in many technologies such as sensor, solar cell, piezoelectric, lightemitting diode and surface acoustic wave (SAW) ${ }^{6,7}$

$\mathrm{ZnO}$ can be easily grown on several substrates in one dimension morphology (1-D) using various methods. Such methods include molecular beam epitaxy, pulsed laser deposition, spray pyrolysis, chemical bath deposition, physical vapour deposition and RF magnetron sputtering..$^{8-13}$ However, most of the methods required sophisticated experiment set-ups and need a high-temperature process. On the other hand, the sol-gel spin coating technique requires lowtemperature synthesis, simple and cheap, does not require high vacuum, and exhibit controllable thickness and good microstructures..$^{14,15}$

The use of dye materials can adsorb a wideband gap spectrum and match the $\mathrm{ZnO}$ bandgap, which is an important characteristic. The dyes that are used as sensitiser can either synthesis or natural dyes. The synthesis dyes, in general, use the Ruthenium complex inorganic-based materials, which is expensive. Besides, the Ruthenium complex contains a heavy metal which is not good for the environmental. Therefore, an organic dye either synthesised or extracted natural dyes are alternative for the DSSC. ${ }^{16}$

Several dyes are used to improve the DSSC efficiency such as dyes extracted from spinach leaves, Luffa cylindrica-L dyes, dragon fruit, hibiscus and bitter leaf 
combination, Roselle (Hibiscus sabdariffa) flowers and pawpaw (Carica papaya) sensitisers. ${ }^{17-20}$ The use of extracted dyes from fruits, leaves and flowers is an important point in improving the DSSC efficiency. Therefore, in this work, we tried to improve the DSSC efficiency by using tamarillo, red dragon fruit, red spinach, boat lily flower and purple hibiscus flower as sensitisers.

\section{EXPERIMENTAL}

\subsection{Synthesis of $\mathrm{ZnO}$ the Thin Films}

$\mathrm{ZnO}$ thin films were synthesised by the sol-gel method. Zinc acetate dehydrate, i.e., $\mathrm{Zn}\left(\mathrm{CH}_{3} \mathrm{COOH}\right) \cdot 2 \mathrm{H}_{2} \mathrm{O}$ of $4.0 \mathrm{~g}$ was added into isopropanol solvent of $35.72 \mathrm{ml}$, and stirred with a magnetic stirrer for $10 \mathrm{~min}$. Next, little by little, diethanolamine (DE) of $1.72 \mathrm{ml}$ was added into the solution to form a sol-gel. The sol-gel then was dropped onto an indium thin oxide (ITO) glass substrate and spun with a spin coating at $2000 \mathrm{rpm}$ speed. To improve the $\mathrm{ZnO}$ thin films, the sample temperature was increased gradually for $5 \mathrm{~h}$ to $250^{\circ} \mathrm{C}$ (pre-heating) followed by increasing gradually for another $5 \mathrm{~h}$ to $500^{\circ} \mathrm{C}$ (post-heating). The $\mathrm{ZnO}$ thin films were then characterised by using XRD (6100 Shimadzhu), SEM (Zeiss EVO MA 10) and UV-Vis (T70+ UV-Vis Spectrometer PG Instrument Ltd.) for structural, morphological and optical properties. ${ }^{21}$ The analysis sample was kept at the Universitas Negeri Medan Laboratory, Medan, Indonesia.

\subsection{Synthesis of the $\mathrm{ZnO} /$ Natural Dyes}

The dye sources, namely tamarillo, red dragon fruit, red spinach, boat lily flower and purple hibiscus flower were cut into small pieces and put into beaker glass. The sample was then further crushed with a mortar and then milled until it became soft. Further, the extract was obtained by immersing it in an aquadest and methanol solution and put in a dark place for $24 \mathrm{~h}$. The extracted dyes were heated for $5 \mathrm{~h}$ and diluted with distilled water to obtain the dye solution. The solution was then filtered with a filter paper, put into a container, wrapped with the aluminium foil, and was stored in a dark place to avoid sun rays. The $\mathrm{ZnO} /$ dyes were formed by dipping the $\mathrm{ZnO}$ thin film into natural dyes extract solution with the $\mathrm{ZnO}$ thin film facing up for $24 \mathrm{~h}$ to let the dyes adsorbed by the thin film. The dye $\mathrm{ZnO}$ thin films then were characterised by a UV-Vis spectrometer to determine the best optical properties. The dye-coating $\mathrm{ZnO}$ thin films were made by dipping the $\mathrm{ZnO}$ thin film into a natural dye solution with the $\mathrm{ZnO}$ thin films up to $24 \mathrm{~h}$ to let the dyes adsorbed by the film. 


\subsection{Synthesis of the DSSC}

The DSSC structure was formed by glueing together the $\mathrm{ZnO} /$ dye and a platinum plat by using Surlyn. The $\mathrm{ZnO} /$ dye and platinum were successively used as a working electrode and counter electrode. The Surlyn functioned as a glue and conductor. The DSSC structure was then put on a hot plate with a temperature of $70^{\circ} \mathrm{C}-80^{\circ} \mathrm{C}$ to enable the Surlyn pasting perfectly. Further, electrolyte liquid was injected into the $\mathrm{ZnO} /$ dye-platinum structure. ${ }^{22}$

\subsection{Efficiency Measurement}

The experiment set up for measuring the DSSC efficiency is shown in Figure 1. The circuit consists of DSSC and an analogue-digital multimeter. Each sample was stacked with a layer of carbon electrodes, clamped with a paper clip, and then connected to a series circuit to determine the current and voltage values. The test was based on the sunlight-lighting method to determine the performance and efficiency of cells, obtained when the solar cell is exposed to light with a certain intensity on the top part of the electrode (anode). DSSC output is an open-circuit voltage $\left(\mathrm{V}_{\mathrm{OC}}\right)$ and short-current circuit $\left(\mathrm{I}_{\mathrm{SC}}\right)$. Then the filling factor $(\mathrm{FF})$ and DSSC efficiency $(\eta)$ were calculated.

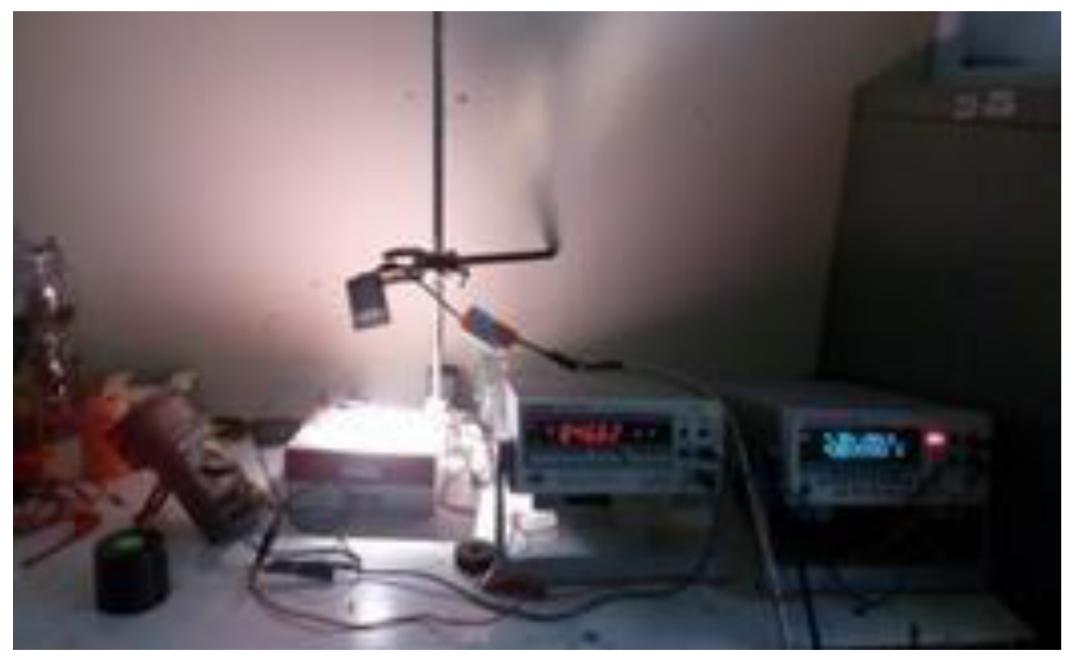

Figure 1: The DSSC efficiency measurement equipment. 


\section{RESULTS AND DISCUSSION}

\subsection{ZnO Thin Film Structure}

The XRD diffraction pattern of the $\mathrm{ZnO}$ thin film is shown in Figure 2. The diffraction pattern shows that the XRD has the same planes, which are (013), (103) and (112) planes, peaking at (112). This result shows that the $\mathrm{ZnO}$ thin film structure is in the wurtzite hexagonal form with the direction oriented along c-axis perpendicular to the substrate surface and along with standard data of ZnO JCPDS 80-0075 card. The crystallite size was obtained using the Scherrer equation:

$$
D=\frac{0,9 \lambda}{\beta \cos \theta}
$$

where $D=$ crystal size, $\lambda=$ wavelength, $\beta=$ full-width at the half-maximum (FWHM) and $\theta=$ diffraction angle. The crystallite size of the $\mathrm{ZnO}$ thin film was $27.3 \mathrm{~nm}$. The annealing treatment may also improve the grain crystallinity. ${ }^{23}$

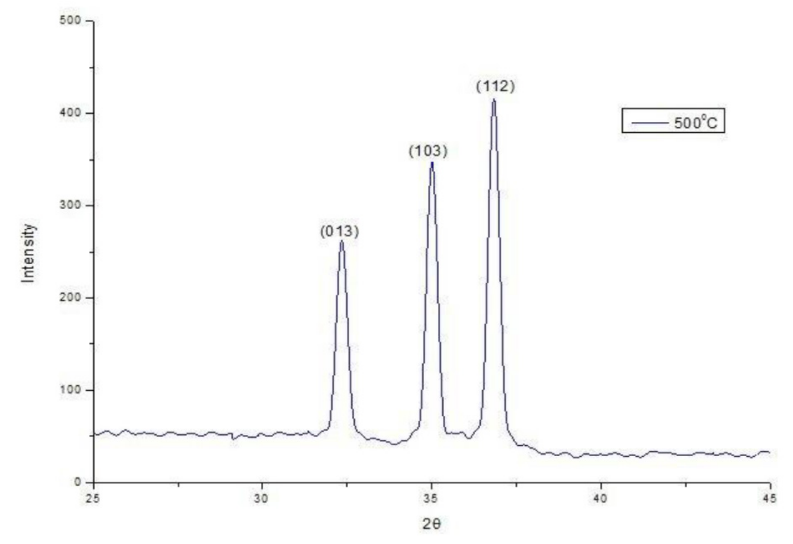

Figure 2: $\mathrm{ZnO}$ thin film XRD spectrum.

\subsection{Morphology of the $\mathrm{ZnO}$ Thin Film}

The $\mathrm{ZnO}$ thin film morphology, which was synthesised with post-heating $500^{\circ} \mathrm{C}$, was shown by the SEM image in Figure 3. The image shows that the $\mathrm{ZnO}$ thin film morphology consists of uniform high-density granules with a narrow inter granules boundary. The atoms of smaller granules have sufficient driving force to defuse and form bigger new granules. As a result of inter granules diffusion, the distance between granules become narrower (necking), and therefore, the thin film surface becomes less porous and smooth. 


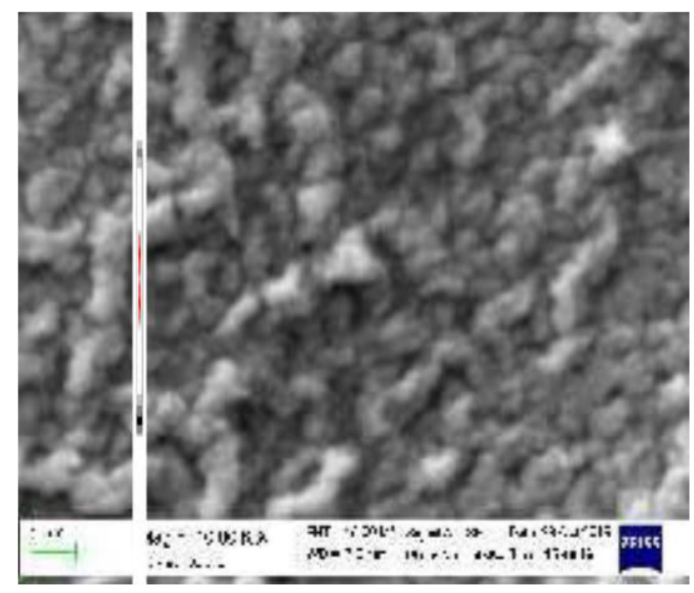

Figure 3: SEM image of the $\mathrm{ZnO}$ thin-film.

\subsection{Optical Properties of the $\mathrm{ZnO}$ Thin film}

The transmission and adsorption spectra were taken in the 300-800 $\mathrm{nm}$ range, shown in Figures 4 and 5. The transmittance spectrum shows a sharp increase in the transmittance value in the wavelength range of wavelengths of $338 \mathrm{~nm}$ to $410 \mathrm{~nm}$ and stable in the range over $410 \mathrm{~nm}$ wavelength. The lowest and highest transmittance values are consecutively $23.1 \%$ and $96.6 \%$. The $\mathrm{ZnO}$ thin film has high transmission in the visible light range, so it is useful in the optoelectronic application as a transparent window material. ${ }^{12,24}$ The lowest and highest absorbance values are consecutively 0.05 au and 0.49 au.

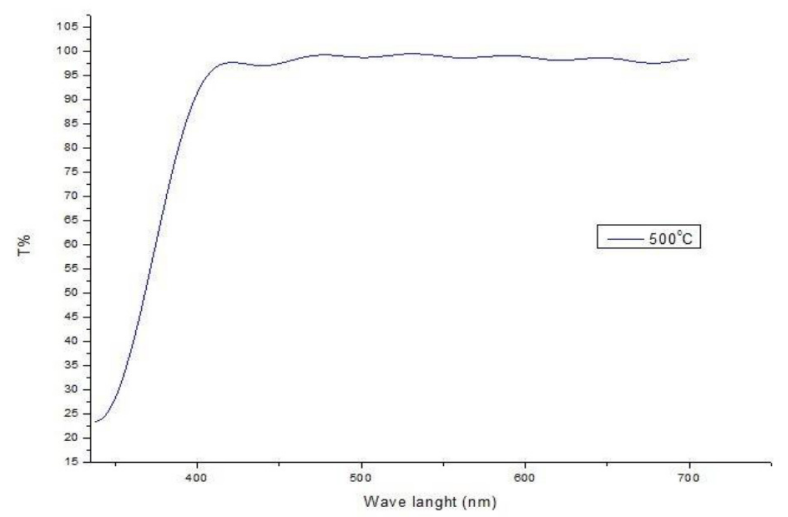

Figure 4: $\mathrm{ZnO}$ thin-film transmittance spectrum. 


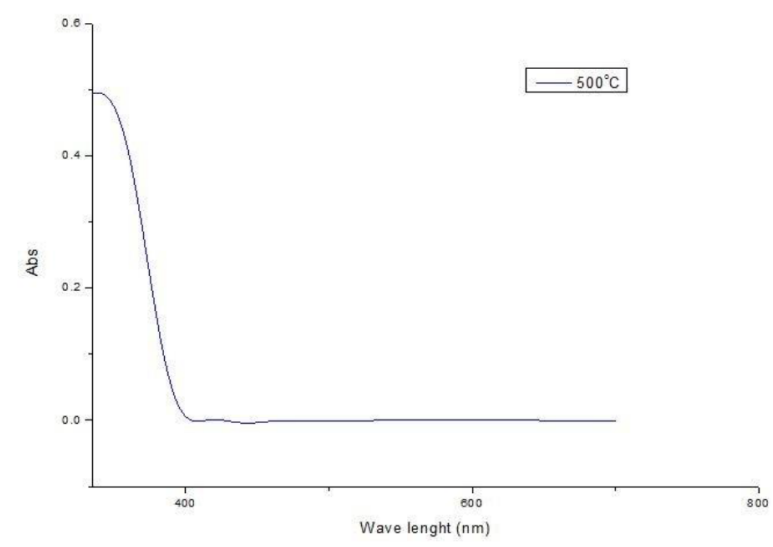

Figure 5: $\mathrm{ZnO}$ thin-film absorption spectrum.

In a material with a direct bandgap, the optical property of the $\mathrm{ZnO}$ thin film can be obtained from the following equation: ${ }^{5}$

$$
(\alpha h \nu)^{2}=C_{D}\left(h v-E_{\text {opt }}\right)
$$

where $\alpha=$ adsorption coefficient, $h=$ Planck's constant, $v=$ photon frequency, $C_{D}=$ constant and $E_{\text {opt }}=$ gap energy.

Figure 6 shows a graph based on the Tauc plot method, indicating that the $\mathrm{ZnO}$ thin film bandgap is $3.25 \mathrm{eV}$.

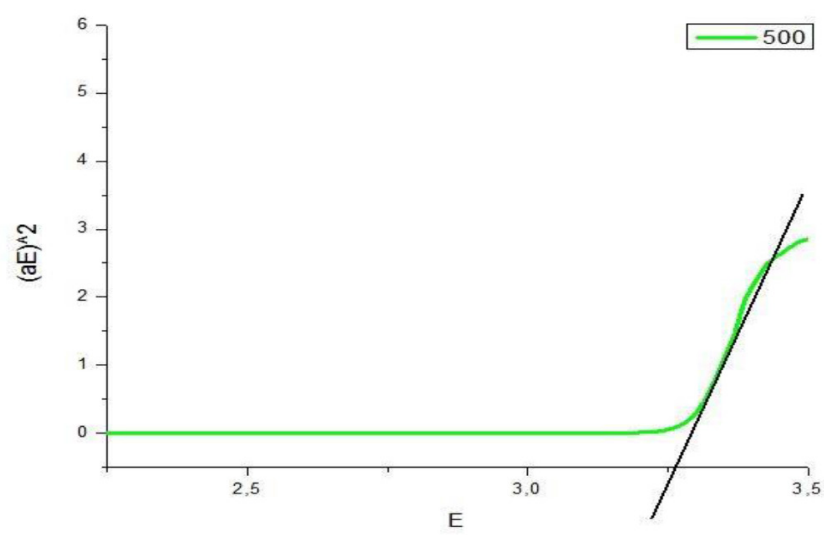

Figure 6: The $\mathrm{ZnO}$ thin film bandgap using the Tauc plot method. 


\subsection{Optical Properties of Natural Dyes}

The dye extracts of tamarillo, red dragon fruit, red spinach, boat lily flower and purple hibiscus flower were tested with UV-vis spectrometer to see the absorbance amount. The UV-vis spectrometer of the natural dyes is shown in Figure 7.

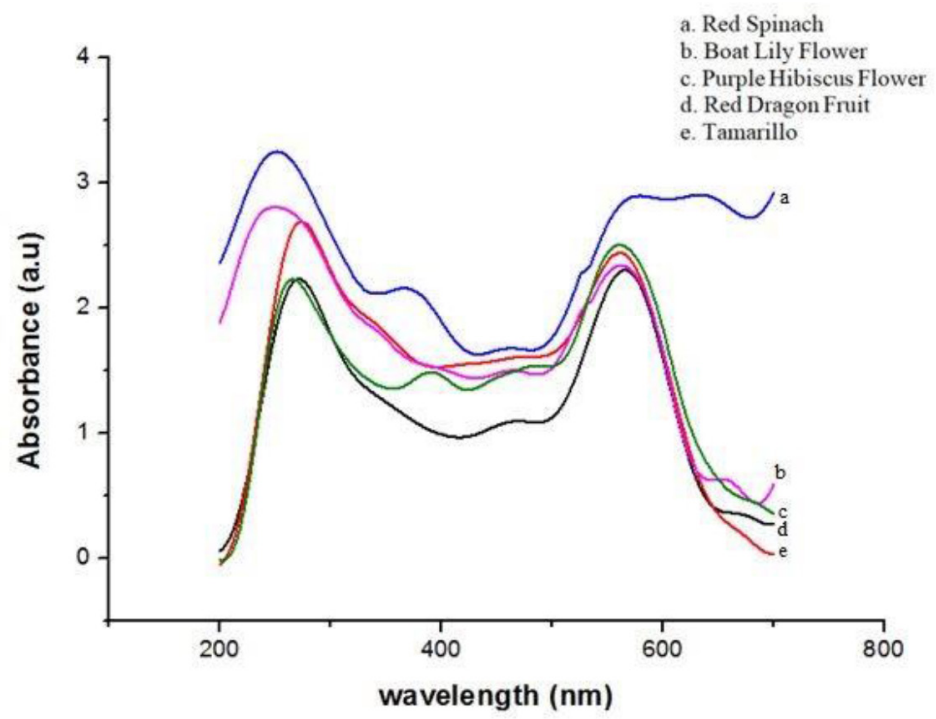

Figure 7: Wavelength vs. absorption of natural dye solutions.

Table 1 shows the highest absorption values, based on Figure 7, of tamarillo (2.78 au at $330 \mathrm{~nm}$ wavelength), red dragon fruit (2.29 au at $328 \mathrm{~nm}$ ), red spinach (3.30 au at $242 \mathrm{~nm}$ ), purple hibiscus flower $(2.90$ au at $246 \mathrm{~nm}$ ), and boat lily flower (2.50 au at $415 \mathrm{~nm}$ ). The UV-Vis spectrometer absorption spectrum was taken in the range of 200 to $800 \mathrm{~nm}$.

Table 1: Natural dye absorption solutions.

\begin{tabular}{lcc}
\hline Dyes & Wavelength $(\mathrm{nm})$ & Absorbance values $(\mathrm{au})$ \\
\hline Tamarillo & 330 & 2.78 \\
Red dragon fruit & 328 & 2.29 \\
Red spinach & 242 & 3.30 \\
Purple hibiscus flower & 246 & 2.90 \\
Boat lily flower & 415 & 2.50 \\
\hline
\end{tabular}


Based on these results, each colour contains anthocyanin pigment with the ability to absorb energy based on a certain wavelength. ${ }^{19}$ Anthocyanin are a group of polyphenolic pigment found in the plant, water-soluble vacuolar pigments that may appear as red, purple, blue or black. This result shows that the higher the anthocyanin value in the dye, the higher its energy absorption is. ${ }^{25}$ The energy absorption mechanism is used in the proses of the energy transduction in a solar cell. ${ }^{19}$ The photoelectric effect was influenced by anthocyanin values of the dye substances. ${ }^{19,26}$

\subsection{DSSC Efficiency}

The efficiency percentage can be obtained by comparing the generated maximum power of the DSSC prototype $\left(P_{\max }\right)$ with the power given by the light source in Equations 3 and 4.

$$
\begin{aligned}
& \eta=\frac{P_{\max }}{P_{\text {light }}} \\
& P_{\text {max }}=V_{\text {max }} \times J_{\text {max }}
\end{aligned}
$$

where $\eta=\mathrm{DSSC}$ efficiency $(\%), P_{\max }=\operatorname{maximum}$ power $\left(\mathrm{W} \mathrm{cm}^{-2}\right)$, $V_{\max }=$ maximum voltage (Volt), $J_{\max }=$ maximum current density $\left(\mathrm{mA} \mathrm{cm} \mathrm{cm}^{-2}\right.$ ), $P_{\text {light }}$ sunlight power per unit area $\left(\mathrm{W} \mathrm{cm}^{-2}\right)$.

The electrical measurement was conducted on each tamarillo, red dragon fruit, red spinach, purple hibiscus flower and boat lily flower-based DSSC. The electrical properties calculated by Equations 3 and 4 are shown in Table 2 .

Table 2: Electrical voltage values, current density and DSSC dye efficiency.

\begin{tabular}{lcccccc}
\hline Natural dye variety & $\begin{array}{l}V_{O C} \\
(\mathrm{~V})\end{array}$ & $\begin{array}{c}J_{S C} \\
\left.(\mathrm{~mA} \mathrm{~cm})^{-2}\right)\end{array}$ & $\begin{array}{c}P_{\max } \\
\left(\mathrm{W} \mathrm{cm}^{-2}\right)\end{array}$ & $\begin{array}{c}P_{\text {in }} \\
\left(\mathrm{W} \mathrm{cm}^{-2}\right)\end{array}$ & $\begin{array}{c}F F \\
(\%)\end{array}$ & $\begin{array}{c}\eta \\
(\%)\end{array}$ \\
\hline Tamarillo & 0.45 & 0.400 & 0.035 & 36.5 & 19.794 & 0.097 \\
Red dragon fruit & 0.50 & 0.281 & 0.030 & 36.5 & 48.214 & 0.082 \\
Red spinach & 0.35 & 0.187 & 0.015 & 36.5 & 17.778 & 0.041 \\
Boat lily flower & 0.45 & 0.712 & 0.101 & 36.5 & 31.676 & 0.278 \\
Purple hibiscus flower & 0.45 & 0.487 & 0.036 & 36.5 & 29.250 & 0.100 \\
\hline
\end{tabular}

Table 2 shows the electrical properties variation of DSSC efficiencies based on the dyes used. The highest and the lowest maximum power were the boat lily flower and red spinach DSSC-based prototypes. The power variation also gives 
the variation in the DSSC efficiency. The variation in the efficiencies is due to transfer energy mechanism where each dye molecule contains various anthocyanin pigments that absorb at a certain wavelength. ${ }^{19,21}$ The higher the anthocyanin values of the dyes, the higher the absorption ability is. ${ }^{17}$ This is why the DSSC efficiency of the DSSC with sensitiser of boat lily flower is the highest. The energy absorption mechanism is also used in the energy transduction process in solar energy. ${ }^{27}$ The absorbance value affects the number of photons absorbed, in which more photons can be excited to be converted by the solar cell to electrical energy. Therefore, the higher the absorption values of the dye solution, the higher the DSSC efficiency is. Previous studies show that the DSSC efficiency depends on the anthocyanin concentration conceived by certain fruits or leaves. ${ }^{25,26}$ However, in this work we found out that the boat lily flower-based DSSC has the highest efficiency among the five dyes which is $0.27 \%$, although the red spinach solution absorption (3.30 au) is higher than the boat lily flower $(2.50 \mathrm{au})$. This might be due to light wavelength absorption of boot lily flower, which was $415 \mathrm{~nm}$ is the range of visible light compared to the wavelength of red spinach solution, which was $242 \mathrm{~nm}$.

\section{CONCLUSION}

DSSC can be fabricated using $\mathrm{ZnO}$ semiconductor and dyes extracted from tamarillo, red dragon fruit, red spinach, purple hibiscus flower and boat lily flower, which were used as a sensitiser. The $\mathrm{ZnO}$ thin film was successfully synthesised by using spin coating sol-gel method. The $\mathrm{ZnO}$ thin film structure was hexagonal with a crystallite size of $27.3 \mathrm{~nm}$, high-density granules with narrow inter granules boundary, and bandgap of $3.25 \mathrm{eV}$. The maximum and minimum sensitisers successively extracted were red spinach (3.30 au) and red dragon fruit 2.29 (au). The highest efficiency and power among the five dyes based-DSSC were boat lily flower which were $0.278 \%$ and $0.101 \mathrm{~W} \mathrm{~cm}^{-2}$.

\section{ACKNOWLEDGEMENTS}

This work was supported by the Indonesia Directorate of Research and Community Service (DRPM) no. 027/UN33.8/LL/2018 and Universitas Negeri Medan Laboratory, Medan, Indonesia. 


\section{REFERENCES}

1. Grätzel, M. (1998). Demonstrating electron transfer and nanotechnology: A natural dye-sensitized nanocrystalline energy converter. J. Chem. Edu., 75(6), 752. https:// doi.org/10.1021/ed075p752

2. Grätzel, M. (2003). Dye sensitized solar cell. J. Photochem. Photobiol. C Photochem. Rev., 4(2),145-53. https://doi.org/10.1016/S1389-5567(03)00026-1

3. Hamady, S. O. S. et al. (2019). Development of novel thin film solar cells: Design and numerical optimisation. J. Phys. Sci., 30(2), 199-205. https://doi.org/10.21315/ jps2019.30.s2.17

4. Caglar, Y. et al. (2009). Crystalline structure and morphological properties of undoped and Sn doped ZnO thin films. Superlatt. Microstruct., 46(3), 469-475. https://doi.org/10.1016/j.spmi.2009.05.005

5. Siregar, N. (2015). The effect of concentration of structure an optical properties of thin films shynthesized by sol-gel methods spin coating. Int. J. Sci. Basic Appl. Res., 22(1), 428-434.

6. Mitra, P. \& Mondal, S. (2013). Structural and morphological characterization of ZnO thin films synthesized by SILAR. Prog. Theor. Appl. Phys., 1, 17-31

7. Nkrumah, I. et al. (2013). Synthesis and characterization of $\mathrm{ZnO}$ thin films deposited by chemical bath technique. Int. J. Res. Eng. Technol., 2(12), 809-812. https://doi.org/10.15623/ijret.2013.0212135

8. Wang, C. et al. (2009). Effect of the oxygen pressure on the microstructure and optical properties of $\mathrm{ZnO}$ films prepared by laser molecular beam epitaxy. Phys. $B$ Condens. Matt., 404(21), 4075-4082. https://doi.org/10.1016/j.physb.2009.07.165

9. Villanueva, Y. Y., Liu, D. R. \& Cheng, P. T. (2006). Pulsed laser deposition of zinc oxide. Thin Solid Films, 501(1-2), 366-369. https://doi.org/10.1016/j. tsf.2005.07.152

10. Krunks, M. et al. (2008). Nanostructured solar cell based on spray pyrolysis deposited ZnO nanorod array. Sol. Energy Mater. Sol. Cells, 92(9), 1016-1019. https://doi.org/10.1016/j.solmat.2008.03.002

11. Kathalingam, A. et al. (2010). Chemical bath deposition and characterization of nanocrystalline ZnO thin films. Mater. Sci. Pol., 28(2), 513-522.

12. Lee, J. C. et al. (2000). RF sputter deposition of the high-quality intrinsic and n-type $\mathrm{ZnO}$ window layers for $\mathrm{Cu}(\mathrm{In}, \mathrm{Ga}) \mathrm{Se} 2-$ based solar cell applications. Sol. Energy Mater. Sol. Cells, 64(2), 185-195. https://doi.org/10.1016/S0927-0248(00)00069-6

13. Wang, M. et al. (2012). Recent developments in redox electrolytes for dyesensitized solar cells. Energy Environ. Sci., 5(11), 9394-9405. https://doi. org/10.1039/C2EE23081J

14. George, A. et al. (2010). Microstructure and field emission characteristics of $\mathrm{ZnO}$ nanoneedles grown by physical vapor deposition. Mater. Chem. Phys., 123(2-3), 634-638. https://doi.org/10.1016/j.matchemphys.2010.05.029

15. Siregar, N. \& Motlan. (2018). The effect of pre-heating temperature on structural and optical properties $\mathrm{ZnO}$ thin film synthesized using sol-gel spin coating method. J. Phys. Conf. Ser., 1120(012088). https://doi.org/10.1088/1742$6596 / 1120 / 1 / 012088$ 
16. Ernawita, E. et al. (2017). Preparasi dan karakterisasi dye-sensitized solar cell (DSSC) dengan pewarna ekstrak jeruk: Pengaruh variasi komposisi karotenoid dan flavonoid terhadap efisiensi sel surya. J. Fis. Apl., 13(3), 103-108.

17. Wongcharee, K., Meeyoo, V. \& Chavadej S., (2007). Dye-sensitized solar cell using natural dyes extracted from rosella and blue pea flowers. Sol. Energy Mater. Sol. Cells, 91(7), 566-571. https://doi.org/10.1016/j.solmat.2006.11.005

18. Maurya, I.C., Srivastava, P. \& Bahadur, L. (2016). Dye-sensitized solar cell using extract from petals of male flowers Luffa cylindrica L. as a natural sensitizer. Opt. Mater. (Amst)., 52, 150-156. https://doi.org/10.1016/j.optmat.2015.12.016

19. Hariyadi, A., Swasono, M. A. \& Augusty, A. C. (2017). Combination of dragon fruit, hibiscus and bitterleaf as dye sensitizer to increase efficiency of DSSC. Int. J. Adv. Sci. Eng. Inf. Technol., 7(3), 936-942. https://doi.org/10.18517/ ijaseit.7.3.2445

20. Eli, D. et al. (2016). Dye-sensitized solar cells using natural dyes extracted from roselle (Hibiscus sabdariffa) flowers and pawpaw (Carica papaya) leaves as sensitizers. J. Energy Nat. Resour., 5(1), 11-15. https://doi.org/10.11648/j. jenr.20160501.12

21. Motlan, Siregar, N. \& Panggabean, J. (2020). The effect of post annealing time on structural and optical properties of $\mathrm{ZnO}$ thin films by sol-gel spin coating method. $J$. Phys. Conf. Ser., 1428(012065). https://doi.org/10.1088/1742-6596/1428/1/012065

22. Motlan \& Siregar, N. (2019). The effect of post-heating time of $\mathrm{ZnO}$ thin film on the efficiency of $\mathrm{ZnO} /$ hylocereus polyrhizus DSSC. Edel. Appl. Sci. Technol., 3(1), 70-74. https://doi.org/10.33805/2576-8484.171

23. Sendi, R. K. \& Mahmud. S. (2013). Stress control in $\mathrm{ZnO}$ nanoparticle-based discs via high-oxygen thermal annealing at various temperatures. J. Phys. Sci., 24(1), $1-15$.

24. Xu, W. J. et al. (2019). Hybrid organic-inorganic perovskites: Polar properties and applications. Coord. Chem. Rev., 387, 398-414. https://doi.org/10.1016/j. ccr.2019.02.012

25. Calogero, G. et al. (2012). Anthocyanin and betalain as light-harvesting pigments for dye-sensitized solar cells. Sol. Energy, 86(5), 1563-1575. https://doi. org/10.1016/j.solener.2012.02.018

26. Lim, A. et al. (2015). Potential natural sensitizers extracted from the skin of Canarium odontophyllum fruits for dye-sensitized solar cells. Spectrochim. Acta A Mol. Biomol. Spectrosc., 138, 596-602. https://doi.org/10.1016/j.saa.2014.11.102

27. Balasingam, S. K. et al. (2013). Improvement of dye-sensitized solar cells toward the broader light harvesting of the solar spectrum. Chem. Commun., 49(15), 14711487. https://doi.org/10.1039/C2CC37616D 